\title{
Nonlinear Behavior of the Radio Frequency Interference (RFI) Sources at Faculty of Applied Sciences, MARA University of Technology
}

\author{
Z. S. Hamidi ${ }^{1, *}$, N. N. M. Shariff ${ }^{2}$ \\ ${ }^{1}$ School of Physics and Material Sciences, Faculty of Sciences, MARA University of Technology, \\ 40450, Shah Alam, Selangor, Malaysia \\ ${ }^{2}$ Academy of Contemporary Islamic Studies (ACIS), MARA University of Technology, \\ 40450, Shah Alam, Selangor, Malaysia \\ *E-mail address: zetysh@salam.uitm.edu.my
}

\begin{abstract}
In this article, we describe and compare several sources of the nonlinear of Radio Frequency Interference (RFI) based on classification methods. It is very important to characterize and understand the nature of interference in as much of the candidate spectrum as possible. Preliminary analysis has been done in 2011. As data sizes of observations grow with new and improved solar monitoring system, the need for completely automated, robust methods for RFI mitigation is highlighted. The current status of RFI noise level is being compared at two different sites (i) indoor and (ii) outdoor. The main objective is to evaluate and find the best range of low frequency in $\mathrm{MHz}$ for the solar monitoring purpose. Our findings are consistent with those of previous studies. There is not much different in terms of the sources of RFI. However, the level of RFI is become increase. Based on the results, it was found that the distribution of RFI sources in indoor site is in the range from -(80-105) $\mathrm{dBm}$. A strong and moderate RFI can be identified in the range of $-100 \mathrm{dBm}$. The dominant sources in this region are due to the fixed mobile signal with 10 points of this signal from 1-2000 MHz. If we compare with outdoor site, the distribution of RFI sources in indoor site is in the range from -(75-105) $\mathrm{dBm}$. It means that the signal of noise is larger compared with indoor site. While new sources strive to remain the increasing of RFI signal levels, numerous factors interact to influence the pattern of this noise. Reporting to the authoritative body should be made to make sure the allocation of the solar monitoring frequency region was not used by other applications. This work is a current scenario of the nonlinear RFI level at our site.
\end{abstract}

Keywords: Radio Frequency Interference (RFI); RFI sources; solar radio burst; CALLISTO

\section{INTRODUCTION}

The Radio Frequency Interference (RFI) is located mostly, but not always, highly populated urban areas and become one of the main issues in solar monitoring in radio region. Mostly, the strong and moderate RFI is due to the technology application for human purpose. There is also a weak RFI from natural geophysical variability. Previous study focused on the number of RFI sources, classifying and characterizing the strength of the RFI profile in 
Universiti Teknologi MARA [1]. We also compare RFI profile indoor (Faculty of Applied Sciences) and outdoor sites (Square Parade). Different approaches have been evaluated in order to investigate the minimum RFI for radio astronomy purpose. Radio astronomy observation may be made in the bands 13.36-13.41 MHz (solar), (25.55-25.67) MHz (Jupiter) and (37.50-38.25) $\mathrm{MHz}$ [2].

The E-CALLISTO network was started since 2002 with Blein Switzerland is the first site that launched the system [3]. Since then, there are more than 40 sites around the world that monitor the Sun activity within 24 hours until 2014. MARA University of Technology, University of Malaya, and the National University of Malaysia and National Space Agency (ANGKASA) are the universities and government agencies that involve this research [4]. In 2011, preliminary analysis of the Radio Frequency Interference (RFI) indication has been done $[5,6]$. We also have analyzed the RFI pattern due to population density, which is specifically for the solar monitoring purpose [7].

\section{THE RADIO FREQUENCY INTERFERENCE MONITORING AND THE CALLISTO SYSTEM}

The radio frequency interference monitoring is very important in radio astronomy observation [8]. Different altitude of observation will effect on RFI level or the noise environment to radio astronomy [9]. We have joined the E-Callisto network under the International Space Weather Initiative (ISWI) for solar monitoring study [10,11]. Our site has become the 19th site that participates the solar burst monitoring and an observational of Radio Frequency Interference (RFI) been done [12]. This research has been started since February 2012 at the National Space Centre; Selangor, Malaysia [13]. The Earth environment has a close connection with Sun activities [14]. Therefore, it is very important to study the solar radio burst data associated with solar flares and Coronal Mass Ejections (CMEs) [1517]. These phenomena are due to the behaviour of the sunspots or active region [18]. The solar activities indirectly affected the conditions of earth's climate and space weather $[19,20]$.

\section{RESULTS AND ANALYSIS}

In conducting the case studies and for better data analyses, we have identified each source of RFI in details. The experiment was done from 9:00 am to 17:00 pm within 2 days. From the data,each site shows a weak and strong of noise. Most of the RFI sources can be found in the region within $-100 \mathrm{dBm}$. Our aim is to focus what kind of signal that might affect the solar monitoring data for every $100 \mathrm{MHz}$.

It should be noted that the calibration of RFI in solar burst data is very important to calculate the actual value of solar burst that associated with the solar flares and Coronal Mass Ejections (CMEs) associated with different types of solar bursts [21,22]. Up to date, we only focused on the short term variability of solar flares and Coronal Mass Ejections events [23]. The data is then can be compared with an X-ray region data [24]. These events are associated with different types of solar bursts [25,26]. Table 1 and 2 lists the RFI sources of indoor and outdoor sites at Faculty of Applied Sciences, MARA University of Technology. A detailed sources of RFI is diagrammed below. 
Table 1. Results of an average signal level (noise floor) and resources of RFI from $1 \mathrm{MHz}$ to 2000 $\mathrm{MHz}$ at indoor Faculty of Applied Sciences.

\begin{tabular}{|c|c|c|c|c|}
\hline $\begin{array}{l}\text { Frequency } \\
\qquad(\mathrm{MHz})\end{array}$ & $\begin{array}{l}\text { RFI maximum } \\
\text { point }\end{array}$ & $\begin{array}{l}\text { Level of signal } \\
\qquad(\mathrm{dBm})\end{array}$ & RFI Sources & $\begin{array}{l}\text { Average level of } \\
\text { signal within the } \\
\text { range }(\mathrm{dBm})\end{array}$ \\
\hline $1-100$ & 1 & -81.66 & Broadcasting & -100.65 \\
\hline $100-200$ & 114.375 & -100.44 & $\begin{array}{c}\text { Aeronautical } \\
\text { Radionavigation }\end{array}$ & -99.62 \\
\hline $200-300$ & 264.375 & -101.05 & Fixed mobile & -102.64 \\
\hline $300-400$ & 323.75 & -102.53 & $\begin{array}{c}\text { Aeronautical } \\
\text { Radionavigation }\end{array}$ & -101.58 \\
\hline $400-500$ & 420.825 & -98.16 & Fixed mobile & -100.31 \\
\hline $500-600$ & 550 & -100.51 & Broadcasting & -99.75 \\
\hline $600-700$ & 650 & -100.57 & Broadcasting & -100.75 \\
\hline $700-800$ & 745.625 & -101.12 & Broadcasting & -100.34 \\
\hline $800-900$ & 865 & -100.25 & Fixed mobile & -99.68 \\
\hline $900-1000$ & 921.25 & -101.91 & Fixed mobile & -100.25 \\
\hline $1000-1100$ & 1036.875 & -95.42 & Fixed mobile & -99.64 \\
\hline $1100-1200$ & 1200 & -93.57 & $\begin{array}{c}\text { Aeronautical } \\
\text { Radionavigation }\end{array}$ & -100.24 \\
\hline $1200-1300$ & 1202.5 & -95 & $\begin{array}{c}\text { Aeronautical } \\
\text { Radionavigation }\end{array}$ & -101.04 \\
\hline $1300-1400$ & 1329.357 & -99.375 & Radiolocation & -100.73 \\
\hline $1400-1500$ & 1433.75 & -99.95 & Fixed mobile & -100.47 \\
\hline $1500-1600$ & 1503.125 & -100.2 & Fixed mobile & -102.17 \\
\hline $1600-1700$ & 1600.625 & -100 & Radiolocation & -101.16 \\
\hline $1700-1800$ & 1766.875 & -101.47 & Fixed mobile & -102.23 \\
\hline $1800-1900$ & 1807.5 & -86.3 & Fixed mobile & -101.06 \\
\hline $1900-2000$ & 1975 & -100.87 & Fixed mobile & -101.10 \\
\hline
\end{tabular}




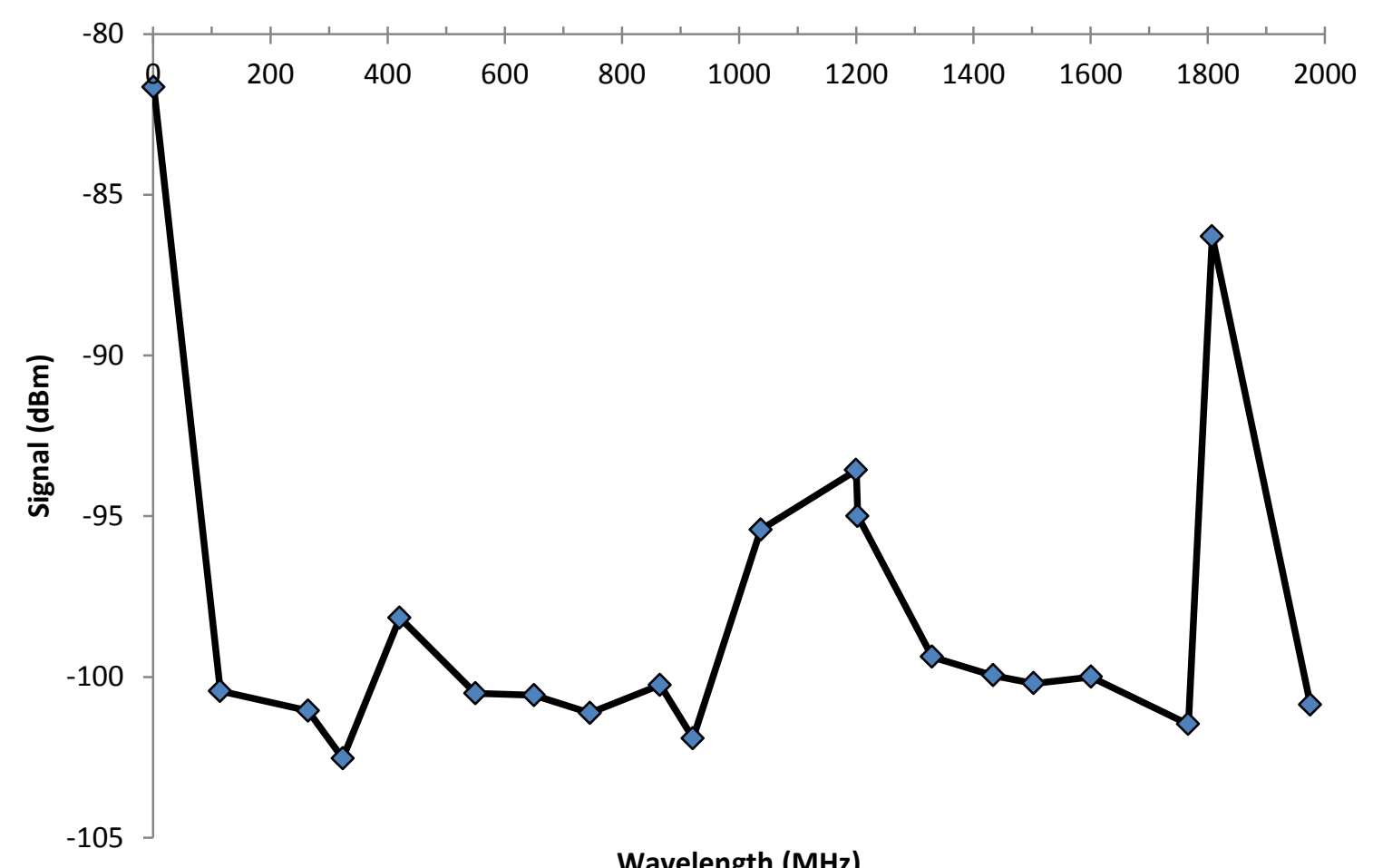

Figure 1. Results of the sources of RFI with peak signal (dBm) from $1 \mathrm{MHz}$ to $2000 \mathrm{MHz}$ at indoor Faculty of Applied Sciences.

Table 2. Results of an average signal level (noise floor) and resources of RFI from $1 \mathrm{MHz}$ to 2000 $\mathrm{MHz}$ at outdoor Faculty of Applied Sciences.

\begin{tabular}{|c|c|c|c|c|}
\hline $\begin{array}{c}\text { Frequency } \\
(\mathrm{MHz})\end{array}$ & $\begin{array}{c}\text { RFI maximum } \\
\text { point }\end{array}$ & $\begin{array}{c}\text { Level of signal } \\
(\mathrm{dBm})\end{array}$ & RFI Sources & $\begin{array}{c}\text { Average level } \\
\text { of signal within } \\
\text { the range }(\mathrm{dBm})\end{array}$ \\
\hline $1-100$ & 1 & -80.77 & Broadcasting & -101.41 \\
\hline $100-200$ & 101 & -89.2 & $\begin{array}{c}\text { Aeronautical } \\
\text { Radionavigation }\end{array}$ & -100.78 \\
\hline $200-300$ & 283.75 & -99.96 & Fixed mobile & -100.58 \\
\hline $300-400$ & 356.875 & -100.56 & Fixed mobile & -101.36 \\
\hline $400-500$ & 496.25 & -100.46 & Fixed mobile & -100.25 \\
\hline $500-600$ & 506.875 & -100.09 & Broadcasting & -100.25 \\
\hline $600-700$ & 646.25 & -100.23 & Broadcasting & -100.51 \\
\hline $700-800$ & 705 & -94.11 & Broadcasting & -101.53 \\
\hline $800-900$ & 865 & -100.94 & $\begin{array}{c}\text { Broadcasting, } \\
\text { Fixed mobile }\end{array}$ & -100.71 \\
\hline
\end{tabular}




\begin{tabular}{|c|c|c|c|c|}
\hline $900-1000$ & 950 & -101.09 & $\begin{array}{c}\text { Broadcasting,Fixed } \\
\text { mobile }\end{array}$ & -100.31 \\
\hline $1000-1100$ & 1020 & -96.00 & $\begin{array}{c}\text { Broadcasting,Fixed } \\
\text { mobile }\end{array}$ & -100.38 \\
\hline $1100-1200$ & 1038.125 & -100.77 & $\begin{array}{c}\text { Aeronautical } \\
\text { Radionavigation }\end{array}$ & -99.78 \\
\hline $1200-1300$ & 1204.375 & -93.62 & $\begin{array}{c}\text { Aeronautical } \\
\text { Radionavigation }\end{array}$ & -99.77 \\
\hline $1300-1400$ & 1340.625 & -99.75 & Radiolocation & -99.76 \\
\hline $1400-1500$ & 1456.25 & -95.00 & $\begin{array}{c}\text { Broadcasting, } \\
\text { Satellite }\end{array}$ & -99.62 \\
\hline $1500-1600$ & 15050 & -75.70 & Satellite & -100.23 \\
\hline $1600-1700$ & 1658.125 & -97 & Satellite & -99.88 \\
\hline $1700-1800$ & 1746.875 & -100.61 & Fixed mobile & -101.40 \\
\hline $1800-1900$ & 1806.3 & -91.25 & Fixed mobile & -100.58 \\
\hline $1900-2000$ & 1975 & -92 & Fixed mobile & -101.10 \\
\hline
\end{tabular}

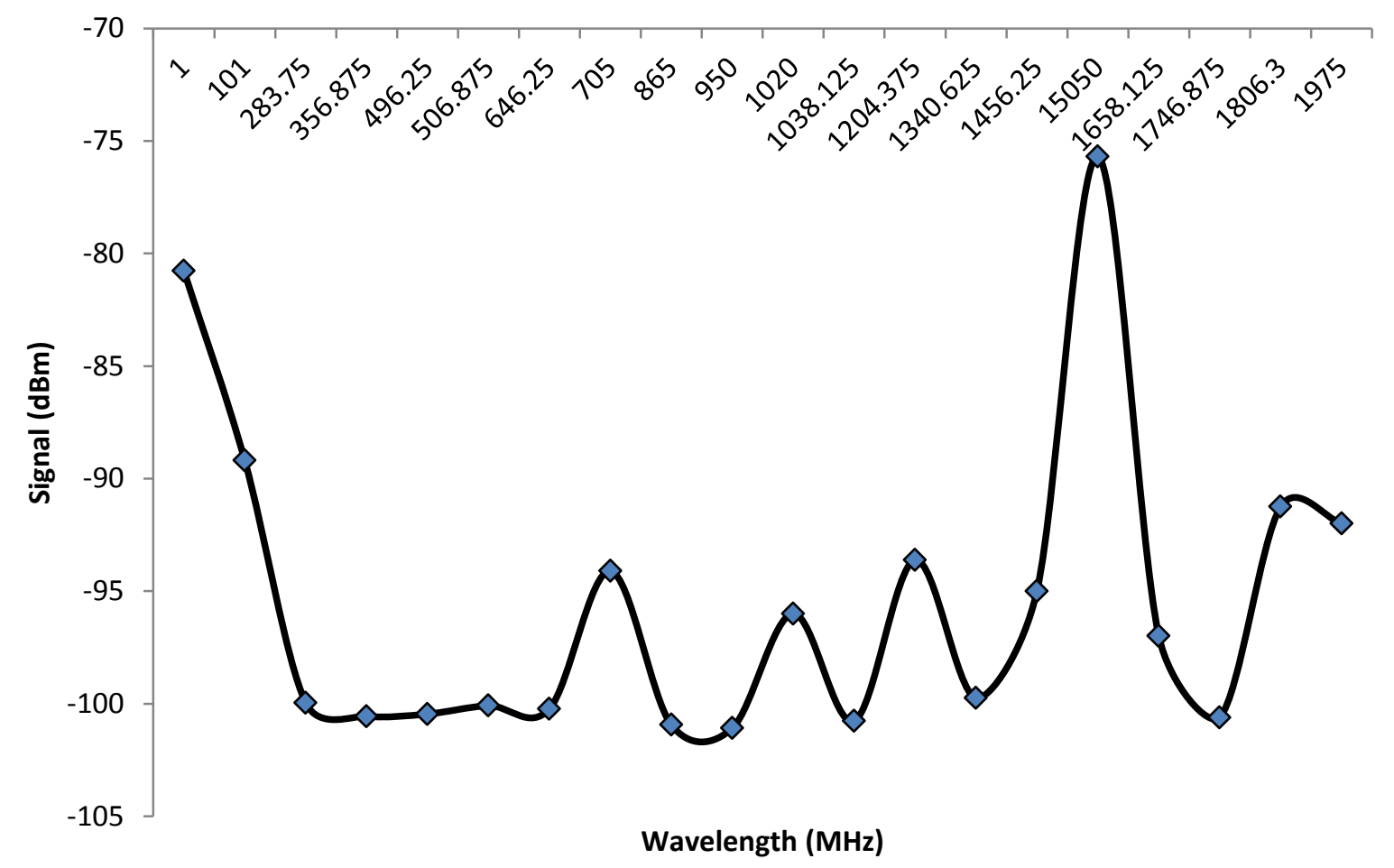

Figure 2. Results of the sources of RFI with peak signal (dBm) from $1 \mathrm{MHz}$ to $2000 \mathrm{MHz}$ at outdoor Faculty of Applied Sciences. 
A key to understanding the RFI signal is to make sure the main region of RFI that might affect the solar burst data should be avoided. Based on the results, it was found that the distribution of RFI sources in indoor site is in the range from -(80-105) dBm. Most of the peak signals are in the range of $-100 \mathrm{dBm}$. The dominant sources in this region are due to the fixed mobile signal with 10 points of this signal from 1-2000 MHz. Other sources came from broadcasting and aeronautical radionavigation signal. On average, the RFI signal that affected the solar monitoring is approximately to $-98.01775 \mathrm{dBm}$. This value can be considered as moderate noise and should be eliminated during the data analysis process.

As is obvious from Figure 2, the noise of RFI vary strongly in intensity at different frequencies. If we compare with outdoor site, the distribution of RFI sources in indoor site is in the range from $-(75-105) \mathrm{dBm}$. It means that the signal of noise is larger compared with indoor site. Most of the peak signals are in the range of $\mathrm{dBm}$. Broadcasting is the most dominant sources of RFI. Other sources came from fixed mobile and aeronautical radionavigation signal. On average, the RFI signal that affected the solar monitoring is approximately to $-94.4555 \mathrm{dBm}$. Keep in mind that these parts in a continuity process and the monitoring should be done from time to time. The difference in detailed on RFI sources and peak signal is illustrated in Figure 3.

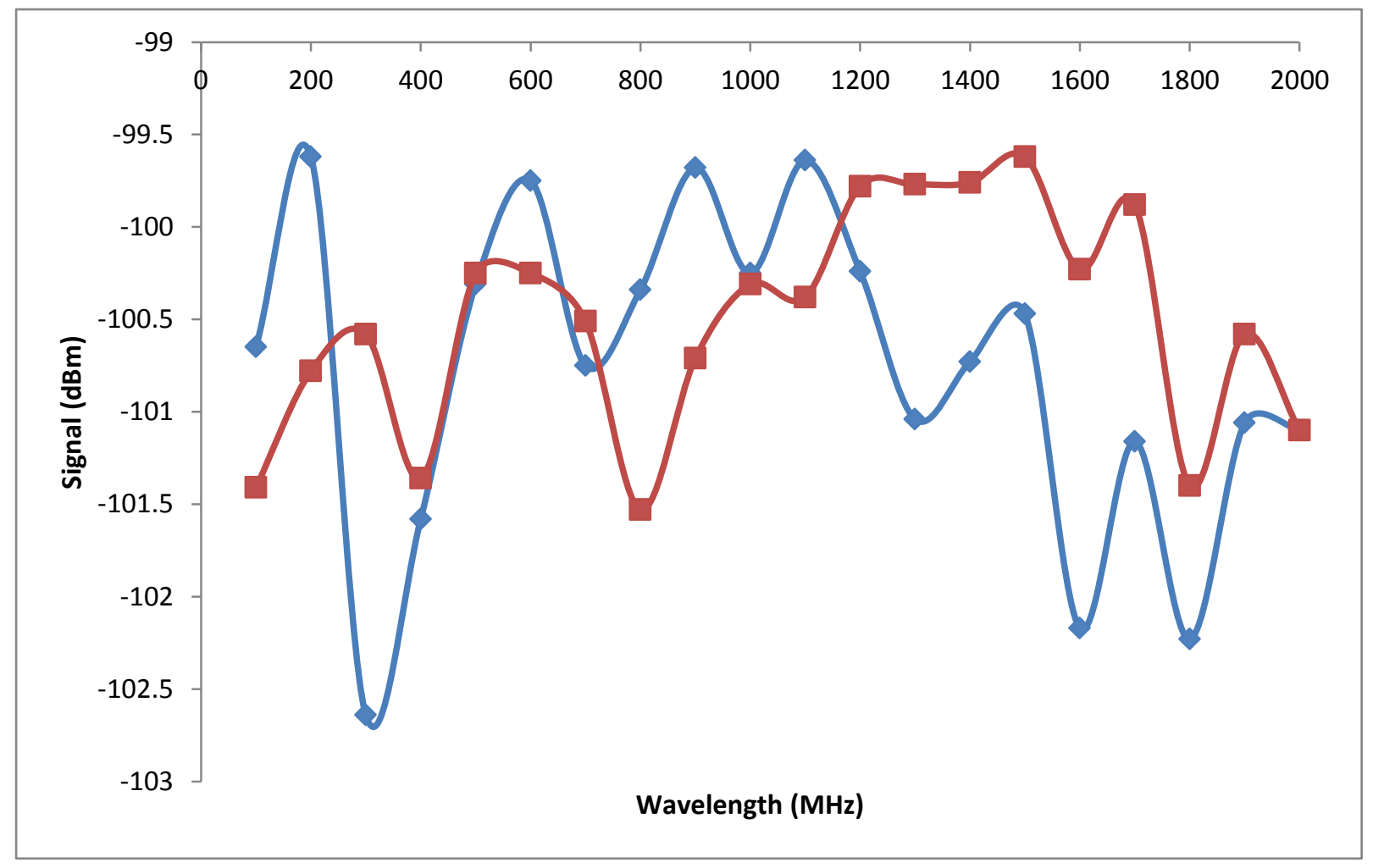

Figure 3. Comparison of the sources of RFI with peak signal (dBm) from $1 \mathrm{MHz}$ to $2000 \mathrm{MHz}$ at indoor (red) and outdoor (blue) of the Faculty of Applied Sciences.

\section{CONCLUSION}

While new sources strive to remain the increasing of RFI signal levels, numerous factors interact to influence the pattern of this noise. Reporting to the authoritative body 
should be made to make sure the allocation of the solar monitoring frequency region was not used by other applications. This work is partly a standard procedure of the calibration process during solar burst monitoring. The importance of Radio Frequency Interference (RFI) needs a dialogue and interactions between different actors and networks. A preliminary analysis of RFI has been published in 2011. Thus, based on the main sources of RFI, the level of signals are not much different compare three years ago. It is hoped that the RFI level can be reduced by actively promote the importance of monitoring the solar activity.

\section{Acknowledgement}

We are grateful to e-CALLISTO network that makes their data available online. This work was partially supported by the FRGS (600 RMI/FRGS 5/3 2012) UiTM grants. Special thanks to the National Space Agency and the National Space Centre for giving us a site to set up this project and support this project. Solar burst monitoring is a project of cooperation between the Institute of Astronomy, ETH Zurich, and FHNW Windisch, Switzerland, MARA University of Technology and University of Malaya. This paper also used NOAA Space Weather Prediction Centre (SWPC) for the sunspot, radio flux and solar flare data for comparison purpose. The research has made use of the National Space Centre Facility and a part of an initiative of the International Space Weather Initiative (ISWI) program.

\section{Biography}

Dr Zety Sharizat Hamidi is currently a senior lecturer and focused in Solar Astrophysics research specifically in radio astrophysics at the School of Physics and Material Sciences, Faculty of Sciences, MARA University of Technology, 40450, Shah Alam, Selangor, Malaysia. Involve a project under the International Space Weather Initiative (ISWI) and also a lecturer in School of Physics and Material Science, at MARA University of Technology, Shah Alam Selangor.

Dr Nur Nafhatun Md Shariff is a senior lecturer in Academy of Contemporary Islamic Studies (ACIS), MARA University of Technology, 40450, Shah Alam, Selangor, MalaysiaHer current research is more on sustainability; environmental aspect. She is looking forward for cross-field research, i.e. solar astrophysics, light pollution measurement (mapping) and religious studies.

\section{References}

[1] Z.S.Hamidi, Z. Abidin, Z. Ibrahim, C. Monstein, N. Shariff, International Journal of Fundamental Physical Sciences 2 (2012) 32-34.

[2] Z. S. Hamidi, N. N. M. Shariff, C. Monstein, W. N. A. Wan Zulkifli, M. B. Ibrahim, N. S. Arifin, N. A. Amran, International Letters of Natural Sciences 5 (2014) 10-17

[3] A.O. Benz, M. Guedel, H. Isliker, S. Miszkowicz, W. Stehling, Sol. Phys. 133 (1991) 385-393.

[4] Z.S.Hamidi, N.N.M.Shariff, Z.Z. Abidin, Z.A. Ibrahim, C.Monstein, Malaysian Journal of Science and Technology Studies 9 (2013) 15-22.

[5] Z.S.Hamidi, Z.Z.Abidin, Z.A. Ibrahim, N.N.M. Shariff, Indication of radio frequency interference (RFI) sources for solar burst monitoring in Malaysia, AIP Conference Proceedings 1454 (2012) 43.

[6] N. Anim, Z.S. Hamidi, Z.Z. Abidin, C. Monstein, N. Rohizat, Radio frequency interference affecting type III solar burst observations, PERFIK 2012, AIP Publisher, Pahang Malaysia, 2012, pp. 5. 
[7] Roslan Umar, Zamri Zainal Abidin, Zainol Abidin Ibrahim, Mohd Saiful Rizal Hassan, Zulfazli Rosli, Z.S.Hamidi, Population density effect on radio frequencies interference (RFI) in radio astronomy, ICPAP 2012, AIP Conference Proceedings, Bandung Indonesia, 2012, pp. 4.

[8] Z.S.Hamidi, N.N.M.Shariff, Evaluation of Signal to Noise Ratio (SNR) of Log Periodic Dipole Antenna (LPDA) Business Engineering and Industrial Applications Colloquium 2013, IEEE, Langkawi, Malaysia, 2013, pp. 434-438.

[9] R. Umar, Z. Abidin, Z. Ibrahim, N. Gasiprong, K. Asanok, S. Nammahachak, S. Aukkaravittayapun, P. Somboopon, A. Prasit, N. Prasert, Middle East Journal of Scientific Research 14 (2013).

[10] Benz A.O. , C. Monstein, H. Meyer, CALLISTO, A New Concept for Solar Radio Spectrometers, Kluwer Academic Publishers, 2004.

[11] A.O. Benz, C. Monstein, H. Meyer, P.K. Manoharan, R. Ramesh, A. Altyntsev, A. Lara, J. Paez, K.-S. Cho, Earth Moon and Planets 104 (2009) 277-285.

[12] Z.S. Hamidi, N. Shariff, Z. Abidin, Z. Ibrahim, C. Monstein, Middle-East Journal of Scientific Research 12 (2012) 6.

[13] Z. Hamidi, N. Shariff, C. Monstein, First Light Detection of A Single Solar Radio Burst Type III Due To Solar Flare Event, (2014).

[14] Z.S. Hamidi, N.N.M. Shariff, C. Monstein, Z. Abidin, Z. Ibrahim, N. Hashim, R. Umar, N. Aziz, International Journal of Fundamental Physical Sciences 3 (2013) 57-63.

[15] Z.S.Hamidi, N.M.Anim, N. N.S.Hakimi, N.Hamzan, A.Mokhtar, N.Syukri, S.Rohizat, I.Sukma, Z.A. Ibrahim, Z.Z.Abidin, N.N.M.Shariff, C.Monstein, International Journal of Fundamental Physical Sciences 2 (2012) 4.

[16] Z.S.Hamidi, Z. Abidin, Z. Ibrahim, N. Shariff, C. Monstein, Observations of coronal mass ejections (CMEs) at low frequency radio region on 15th April 2012, in: R.Shukor (Ed.), PERFIK 2012, American Institute of Physics, Malaysia, 2013, pp. 5.

[17] Z.S. Hamidi, N. Anim, N.N.M. Shariff, Z.Z. Abidin, Z.A. Ibrahim, C. Monstein, Dynamical structure of solar radio burst type III as evidence of energy of solar flares, in: R.Shukor (Ed.), PERFIK 2012, American Institute of Physics, Malaysia, 2013, pp. 11-15.

[18] Z.S. Hamidi, N.N.M. Shariff, F.N.Z. Ulum, Z.Z. Abidin, Z.A. Ibrahim, Time Series Analysis of Variance of Sunspots in January till September 2010 and Correlation with Sunspots Areas, International Journal of Astronomy 5 (2012) 101-106.

[19] Z.S. Hamidi, N.N.M.Shariff, C.Monstein, Z.A. Ibrahim, International Letters of Chemistry, Physics and Astronomy 7 (2014) 37-44.

[20] N. Hashim, Z. Abidin, U. Ibrahim, R. Umar, M. Hassan, Z. Rosli, Z. Hamidi, Z. Ibrahim, Radio Astronomy in Malaysia: Current Status and Outreach Activities, Astronomical Society of the Pacific Conference Series, 2011, pp. 355.

[21] Z.S. Hamidi, N.N.M. Shariff, Thermal Energy and Power Engineering 3 (2014) 181-184.

[22] Z.S. Hamidi, N.N.M.Shariff, International Letters of Chemistry, Physics and Astronomy 4 (2014) 29-36. 
[23] Z.S. Hamidi, N.N.M. Shariff, M.F. Ali, C. Monstein, W.N.A.W. Zulkifli, M.B. Ibrahim, N.S. Arifin, N.A. Amran, International Letters of Chemistry, Physics and Astronomy 9 (2014) 84-92.

[24] Z.S. Hamidi, N.N.M.Shariff, C.Monstein, W.N.A.W. Zulkifli, M.B. Ibrahim, N.S. Arifin, N.A. Amran, International Letters of Chemistry, Physics and Astronomy 8 (2014) 13-19.

[25] Z.S. Hamidi, N.N.M.Shariff, International Letters of Chemistry, Physics and Astronomy 7 (2014) 30-36.

[26] Z.S. Hamidi, N.N.M.Shariff, International Letters of Chemistry, Physics and Astronomy 5 (2014) 32-42. 